\title{
Regulation of prostaglandin production in intact fetal membranes by interleukin-1 and its receptor antagonist
}

\author{
N L Brown, S A Alvi, M G Elder, P R Bennett and M H F Sullivan \\ Department of Maternal and Fetal Medicine, Division of Paediatrics, Obstetrics and Gynaecology, Imperial College School of Medicine, Queen Charlotte's and \\ Chelsea Hospital, Goldhawk Road, London W6 OXG, UK \\ (Requests for offprints should be addressed to M H F Sullivan)
}

\begin{abstract}
There is strong evidence for the involvement of inflammatory mediators such as interleukin (IL)-1 in the biochemical mechanisms of parturition. Therefore the effects of the IL-1 family (IL-1 $\alpha$ (1 ng/ml), IL-1 $\beta$ (1 ng/ $\mathrm{ml})$ and the IL-1 receptor antagonist (IL-1ra) $(10 \mathrm{ng} / \mathrm{ml}))$ on the regulation of prostaglandin synthesis in term human fetal membranes were investigated. It was found that, after $4 \mathrm{~h}$ of culture, IL-1 $\beta$ increased prostaglandin $\mathrm{E}_{2}\left(\mathrm{PGE}_{2}\right)$ output approximately twofold. This was associated with both a significant increase in cyclo-oxygenase-2 (COX-2) mRNA levels (approximately fourfold compared with control) and translocation of cytoplasmic phospholipase $\mathrm{A}_{2}\left(\mathrm{cPLA}_{2}\right)$ from the cytosol to the membrane fraction. IL- $1 \alpha$ was less effective than IL- $1 \beta$ at stimulating PGE $_{2}$ production through similar mechanisms.
\end{abstract}

IL-1ra had no effect on $\mathrm{PGE}_{2}$ output. However, in combination treatments, IL-1ra did not inhibit IL-1 $\alpha$ - or IL-1 $\beta$-stimulated $\mathrm{PGE}_{2}$ output, and increased $\mathrm{PGE}_{2}$ production further compared with IL-1 $\beta$ alone. IL-1 ra decreased IL-1 $\beta$-induced COX-2 mRNA expression by about half and significantly increased $\mathrm{CPLA}_{2}$ protein levels, as detected by immunoblotting, when used alone and together with IL-1 $\beta$. These results suggest that IL-1 ra has partial agonist properties when used together with IL-1 $\alpha$ and IL-1 $\beta$ in fetal membranes by increasing CPLA $_{2}$ protein levels, which leads to an increase in the production of prostaglandins.

Journal of Endocrinology (1998) 159, 519-526

\section{Introduction}

The biochemical signals that initiate human parturition are not completely understood. There is good evidence for prostaglandins, in particular $\mathrm{PGE}_{2}$ and $\mathrm{PGF}_{2 \alpha}$, being important mediators in the onset of human labour by inducing myometrial contractions (Carraher et al. 1983), ripening of the cervix (Ellwood et al. 1980) and membrane rupture (Challis \& Olson 1988). Prostaglandins are produced by the amnion, chorion, decidua, myometrium and placenta (Duchesne et al. 1978, Olson \& Zakar 1993). The precise regulatory mechanisms responsible for their increase at term have not been fully resolved. Many factors can increase prostaglandin production, including cytokines (Mitchell et al. 1991, 1993a, Norwitz et al. 1992, Ishihara et al. 1996) and growth factors (Kniss et al. 1992).

The first step in the synthesis of prostaglandins is the hydrolysis of arachidonic acid from cell membrane phospholipids, predominantly by the action of phospholipase $\mathrm{A}_{2}\left(\mathrm{PLA}_{2}\right)$. There are multiple forms of $\mathrm{PLA}_{2}$ which include the cytosolic group IV ( $\left.\mathrm{CPLA}_{2}\right)$ (Clark et al. 1991), the secretory group $\left(\mathrm{sPLA}_{2}\right)$ (Seilhamer et al. 1989) and a cytosolic $\mathrm{Ca}^{2+}$-independent $\mathrm{PLA}_{2} \quad\left(\mathrm{iPLA}_{2}\right) \quad$ (Buhl et al. 1995). The free arachidonic acid can then be converted to the intermediates $\mathrm{PGG}_{2}$ and $\mathrm{PGH}_{2}$ by the action of prostaglandin $\mathrm{H}$ synthase (alternatively known as cyclo-oxygenase (COX)), and can then be further metabolised to prostaglandins, prostacyclin or thromboxanes. There are two isoforms of COX which are encoded by different genes (Hla et al. 1986, Hla \& Neilson 1992, Takahashi et al. 1992): COX-1, which is constitutively expressed, and COX-2, which can be upregulated in response to stimuli such as cytokines and growth factors (Mitchell et al. 1993a, Albert et al. 1994, Angel et al. 1994).

Fetal membrane $\mathrm{PLA}_{2}$ activity increases throughout gestation (Schultz et al. 1975), and total cellular $\mathrm{CPLA}_{2}$ has also been found to be high before the onset of labour in the amnion and depleted after delivery (Skannal et al. 1997). It has also been shown that IL- $1 \beta$ can rapidly induce cPLA 2 protein expression and activity with a parallel increase in $\mathrm{PGE}_{2}$ synthesis in amnion-derived WISH cells, and that this can be inhibited using a cPLA ${ }_{2}$-specific inhibitor (Xue et al. 1995).

There is evidence for increased amnion COX enzyme activity in association with the onset of labour at term (Smieja et al. 1993, Teixeira et al. 1994) and mRNA expression of COX-2 with the onset of labour (Slater 
et al. 1995, Hirst et al. 1995). Interleukin (IL)-1 $\beta$ has also been reported to increase prostaglandin synthesis in both amnion primary cells and WISH cells by induction of COX-2 mRNA and protein (Mitchell et al. 1993a, Albert et al. 1994).

IL-1 is a proinflammatory cytokine which exists in two biochemically related but distinct forms known as IL-1 $\alpha$ and IL-1 $\beta$. The third member of the family is the receptor antagonist (IL-1ra) which is generally thought to compete with IL- $1 \alpha$ and IL-1 $\beta$ for the cell surface receptor without initiating signal transduction (Arend 1991). There are two types of IL-1 receptor (Sims et al. 1989, McMahan et al. 1991) but only the type 1 receptor (IL-1 R1) has been shown to transduce the IL-1 signal (Sims et al. 1993). IL-1 $\beta$ is found in increased levels in the amniotic fluid of women in preterm labour associated with infection (Romero et al. 1989) as well as spontaneous labour at term (Romero et al. 1990). IL-1ra has been found to prevent IL-1-induced preterm labour in mice (Romero \& Tartakovsky 1992), but other workers have reported that, in cultured human decidual cells, IL-1ra can act as a partial agonist of prostaglandin production (Cole et al. 1993, Mitchell et al. 1993b).

In this study, we have used an intact fetal membrane culture system to investigate how the IL-1 family regulates prostaglandin synthesis and how their effects are modulated by the receptor antagonist.

\section{Materials and Methods}

\section{Tissue collection and culture}

Fetal membranes were collected from uncomplicated pregnancies at term (38-40 weeks gestation) after elective caesarean section in the absence of labour and infection. Patients had not taken any anti-inflammatory drugs for 2 weeks before delivery and were not suffering from pre-eclampsia. Ethics committee approval was obtained to use tissues that would normally be discarded. Tissue was washed with PBS containing 10\% penicillin, streptomycin and L-glutamine (Sigma, Poole, Dorset, UK). Disks of intact tissue were cut using a sharpened punch and cultured in Medium 199 supplemented with ITS (insulin, transferrin, selenium and linoleic acid, all at $0.63 \mathrm{mg} / \mathrm{ml}$, and BSA at $0.13 \mathrm{mg} / \mathrm{ml}$; Sigma) in multiwell tissue culture plates for $24 \mathrm{~h}$ at $37^{\circ} \mathrm{C}$ in an atmosphere of $5 \% \mathrm{CO}_{2} / 95 \%$ air. The medium was also supplemented with $1 \mathrm{mM}$ aspirin, as we have shown that fetal membranes may be preactivated and spontaneously release high levels of $\mathrm{PGE}_{2}$ (Brown et al. 1998). After this time the medium was changed, the tissue washed with medium containing no aspirin, and incubated with or without IL- $1 \alpha$, IL-1 $\beta$ or IL-1ra or combinations of these for time periods stated in the Results section. The tissues were snap-frozen in liquid nitrogen and stored at $-80{ }^{\circ} \mathrm{C}$. The supernatants were then removed and frozen at $-20{ }^{\circ} \mathrm{C}$ until analysis for $\mathrm{PGE}_{2}$ levels by ELISA (Amersham International, Amersham, Bucks, UK). $\mathrm{PGE}_{2}$ levels were then expressed as a fold change relative to the control levels.

\section{$R N A$ extraction and reverse transcriptase (RT)-PCR}

Total RNA was extracted using a standard guanidinium isothiocyanate technique (Chomczynski \& Sacchi 1987) and stored at $-80^{\circ} \mathrm{C}$ until use. RNA samples $(1 \mu \mathrm{g})$ were denatured at $70{ }^{\circ} \mathrm{C}$ for $5 \mathrm{~min}$ and cooled to $37^{\circ} \mathrm{C}$. Reverse transcription was carried out using $\times 1$ first-strand buffer (Gibco, New York, NY, USA), 0.25 $\mu$ g random hexanucleotide primers (Pharmacia, Uppsala, Sweden), $10 \mathrm{mM}$ dithiothreitol, $1 \mathrm{mM}$ each deoxynucleotide triphosphate (dNTP; Gibco), $1 \mathrm{U}$ RNase inhibitor (Pharmacia) and $40 \mathrm{U}$ Moloney murine leukaemia virus reverse transcriptase (Gibco) for $60 \mathrm{~min}$ at $37^{\circ} \mathrm{C}$ in a reaction volume of $20 \mu \mathrm{l}$. The reaction was stopped by incubation at $90{ }^{\circ} \mathrm{C}$ for $4 \mathrm{~min}$, and the resultant cDNA stored at $-80{ }^{\circ} \mathrm{C}$ until PCR amplification.

The COX-1 and COX-2 primers for PCR have been previously reported (Slater et al. 1995). The other primers used were: cPLA $2,5^{\prime}$-GAG CTG ATG TTT GCA GAT TGG GTT-3' (sense) and 5'-GTC ACT CAA AGG AGA CAG TGG ATA AGA-3' (antisense); and sPLA 2 , 5'-GCT GTG TCA CTC ATG ACT GTT-3' (sense) and 5'-GGA GTA CAG CTT CTT TGG TTA-3' (antisense). The glyceraldehyde-3-phosphate dehydrogenase (GAPDH) primers have been described previously (Tso et al. 1985). PCR was performed in a volume of $25 \mu \mathrm{l}$ containing 1:20 volume of the cDNA, $1 \times \mathrm{NH}_{4}$ buffer (Bioline, London, UK), $1.5 \mathrm{mM} \mathrm{MgCl}, 0 \cdot 2 \mathrm{mM}$ dNTP, $125 \mathrm{ng}$ each sense and antisense primer and $0.5 \mathrm{U} \mathrm{Taq}$ polymerase (Bioline). After an initial denaturation step of $2 \mathrm{~min}$ at $94^{\circ} \mathrm{C}$, target cDNA was amplified by denaturing at $94{ }^{\circ} \mathrm{C}$ for $30 \mathrm{~s}$, primer annealing $\left(58{ }^{\circ} \mathrm{C}\right.$ for GAPDH and COX-2; $55^{\circ} \mathrm{C}$ for $\mathrm{sPLA}_{2}$ and $\mathrm{cPLA}_{2}$ ) for $30 \mathrm{~s}$ and primer extension at $72{ }^{\circ} \mathrm{C}$ for $30 \mathrm{~s}$. Cycle profiles were performed as described previously to ensure that the exponential phase was used to amplify the products (Slater et al. 1995). Aliquots of the PCR products were separated by agarose gel electrophoresis and visualised under UV light.

To quantify the PCR results, $5 \mu$ of each PCR mixture was dotted on to Hybond nylon filters. The filters were first washed in denaturing solution $(1.5 \mathrm{M} \mathrm{NaCl}, 0.5 \mathrm{M}$ $\mathrm{NaOH})$, neutralised $(1.5 \mathrm{M} \mathrm{NaCl}, 0.5 \mathrm{M}$ Tris $-\mathrm{HCl}$, $\mathrm{pH} 7 \cdot 5)$ and lastly washed in $3 \times$ sodium citrate buffer $(20 \times$ SSC: $0.3 \mathrm{M} \mathrm{NaCl}, 0.3 \mathrm{M}$ sodium citrate, $\mathrm{pH} 7 \cdot 0)$ for $5 \mathrm{~min}$ each. The DNA was fixed to the filters by UV crosslinking. Filters were first prehybridised for $1-2 \mathrm{~h}$ at $65{ }^{\circ} \mathrm{C}$ followed by hybridisation overnight with the appropriate $\left[{ }^{32} \mathrm{P}\right] \mathrm{dCTP}-l$ labelled cDNA probe at $65^{\circ} \mathrm{C}$. Excess probe was removed by washing in a series of SSC buffer washes containing $0 \cdot 1 \%$ SDS from $3 \times$ SSC down 
to $0 \cdot 1 \times$ SSC. The levels of $\mathrm{cDNA}$ were then determined by $\beta$-counting of the filter sections. Expression of each product was then calculated as a ratio relative to the expression of GAPDH. The ratios were then represented as a fold increase or decrease in mRNA expression.

Immunoblot analysis for protein phosphorylation of cPLA $A_{2}$

Fetal membrane disks were allowed to thaw in $0.5 \mathrm{ml}$ homogenisation buffer $(10 \mathrm{mM}$ Tris- $\mathrm{HCl}, \mathrm{pH} \quad 7 \cdot 4$, $1 \mathrm{mM}$ EDTA and $1 \mathrm{mM}$ sodium orthovanadate) containing the protease inhibitors pepstatin A $(1 \mu \mathrm{M})$, phenylmethylsulphonyl fluoride $(0 \cdot 1 \mathrm{mM})$ and E-64 (trans-epoxysuccinyl-L-leucylamido-(4-guanidino)butane) $(10 \mu \mathrm{M})$. Tissue was homogenised in short bursts on ice and the total lysate was then centrifuged for $10 \mathrm{~min}$ at $13000 \mathrm{~g}$ to pellet cell debris. Protein levels were determined by Bradford assay using BSA as the standard, and $200 \mu \mathrm{g}$ of each sample was loaded on an SDS-12\% polyacrylamide gel. To demonstrate a phosphorylationstimulated shift in $\mathrm{cPLA}_{2}$ mobility (Lin et al. 1992a, Croxtall et al. 1996), the separating gel was made using an acrylamide:bisacrylamide ratio of 30:0 5 . To improve the resolution of the protein bands, $67 \mathrm{mM}$ imidazole was included in both the stacking gel and the sample buffer (Rittenhouse \& Marcus 1984). Purified cPLA 2 (Genetics Institute, Cambridge, MA, USA) was also included on each gel as a positive control. The gels were run overnight until the $29 \mathrm{kDa}$ molecular mass marker had run to the bottom of the gel. The proteins were then electrophoretically transferred to a nitrocellulose filter at $350 \mathrm{~mA}$ for $4 \mathrm{~h}$ in transfer buffer containing $16.5 \mathrm{mM}$ Tris, $191 \mathrm{mM}$ glycine and 20\% methanol. The filter was blocked in PBS containing $0 \cdot 1 \%$ Tween and $5 \%$ non-fat milk for $2 \mathrm{~h}$ at room temperature. $\mathrm{cPLA}_{2}$ protein was detected by incubation of the filter overnight at $4{ }^{\circ} \mathrm{C}$ with a rabbit polyclonal antibody (Santa Cruz, Biotechnology Inc., Santa Cruz, CA, USA) which was diluted $1: 500$ in PBS- $0 \cdot 1 \%$ Tween containing $1 \%$ non-fat milk. This was followed by a $1 \mathrm{~h}$ incubation with an anti-rabbit IgG antibody labelled with peroxidase (Sigma). Immunolocalised proteins were then detected using a chemiluminescent detection system (ECL; Amersham International). The filters were also incubated with a $\beta$-actin goat polyclonal antibody (Santa Cruz) (1:2000 dilution) and then an anti-goat peroxidase-labelled antibody (Santa Cruz) (1:1000 dilution) to verify equal loading of the samples. The filters were stripped using stripping buffer $(100 \mathrm{mM}$ 2-mercaptoethanol, 2\% SDS, $62.5 \mathrm{mM}$ Tris- $\mathrm{HCl}, \mathrm{pH}$ 6.7) and incubated at $50{ }^{\circ} \mathrm{C}$ for $30 \mathrm{~min}$ with occasional agitation. The filter was then washed in PBS-0.1\% Tween, blocked as before and incubated with either a COX-1 or COX-2 goat polyclonal antibody (Santa Cruz) (1:500 dilution). Human platelets were used as a

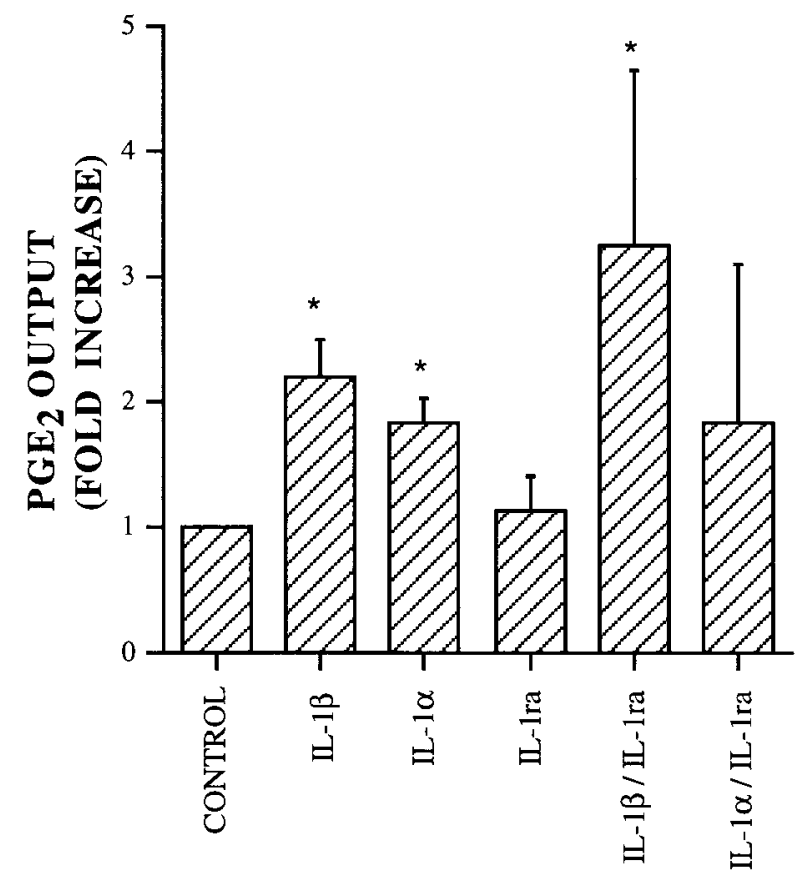

TREATMENT

Figure $1 \mathrm{PGE}_{2}$ output from fetal membranes after incubation with members of the IL- 1 family for $4 \mathrm{~h}$. Concentrations used were $1 \mathrm{ng} / \mathrm{ml}$ for IL- $1 \beta$ and IL- $1 \alpha$, and $10 \mathrm{ng} / \mathrm{ml}$ for IL- 1 ra. PGE $\mathrm{P}_{2}$ output is expressed as a fold increase compared with the control. Results shown are mean \pm S.E.M. for at least five experiments in which each treatment was performed in triplicate. * Statistically significant difference $(P<0 \cdot 05)$.

positive control for COX-1, and, for COX-2, lymphocytes stimulated with lipopolysaccharide were used.

Immunoblot detection of cPLA $A_{2}$ translocation from the cytosol to the membrane

Fetal membrane disks were homogenised in $0.5 \mathrm{ml}$ translocation buffer (25 mM Hepes, pH 7·4, $5 \mathrm{mM}$ EDTA, $50 \mathrm{mM} \mathrm{NaF}$ and $1 \mathrm{mM}$ sodium orthovanadate). The total lysate was then spun for $10 \mathrm{~min}$ at $4{ }^{\circ} \mathrm{C}$ at $13000 \mathrm{~g}$, and the resulting cytosol spun at $100000 \mathrm{~g}$ for $1 \mathrm{~h}$ at $4{ }^{\circ} \mathrm{C}$. This gave cytosolic (supernatant) and membrane (pellet) fractions. The membrane pellet was resuspended in $40 \mu \mathrm{l}$ translocation buffer. Then $100 \mu \mathrm{g}$ of the cytosolic fractions and each membrane fraction were loaded on an SDS-12\% polyacrylamide gel. The proteins were electroblotted, and CPLA $_{2}$ and $\beta$-actin were immunodetected as described above.

Analysis of immunoblots

The autoradiographs of each blot were scanned by a UMAX Mirage D-16L scanner and the integrated density 
(A)

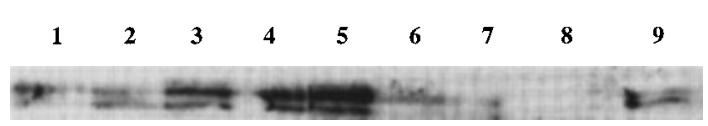

time 0 control IL-1 $\beta$ IL-1 $\alpha$ IL-1ra IL-1 $\beta$ IL-1 $\alpha$ COX-1 COX-2 /IL-1ra /IL-1ra

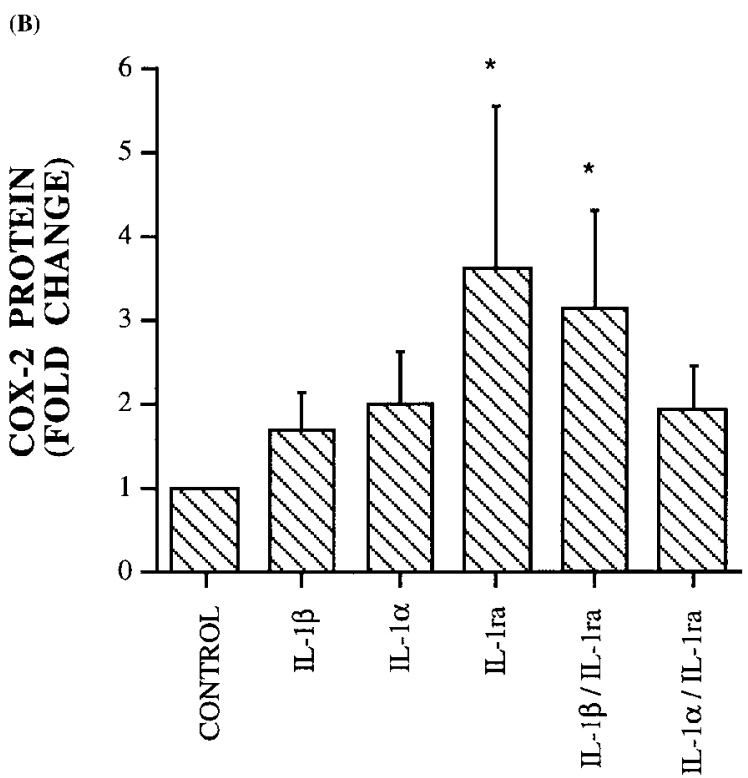

TREATMENT

Figure 2 Changes in COX-2 protein levels after treatment with IL-1 $\beta$, IL- $1 \alpha$ or IL-1ra or combinations of these treatments for $4 \mathrm{~h}$ : (A) typical immunoblot; (B) histographic summary of three such immunoblots analysed by densitometry showing the mean \pm S.E.M. COX-2 levels in each sample were corrected for $\beta$-actin concentration and then expressed as fold change compared with the control level. *Statistically significant difference $(P<0 \cdot 05)$.

of each band determined using the software package Whole Band Analyser (Genomic Solutions Ltd, Eaton Socon, Cambs., UK). The integrated density for $\mathrm{cPLA}_{2}$ or COX was then expressed relative to the density of $\beta$-actin for each sample.

\section{Statistical analysis}

The results are shown as mean \pm S.E.M. For statistical analysis, the results were log-transformed and investigated by ANOVA with post-hoc analysis by Fisher's exact test. Significance was set at $P<0 \cdot 05$.

\section{Results}

We determined the optimum concentration of IL-1 $\beta$ and IL-1 $\alpha$ for stimulating $\mathrm{PGE}_{2}$ production to be $1 \mathrm{ng} / \mathrm{ml}$, and that for IL-1ra was $10 \mathrm{ng} / \mathrm{ml}$. IL-1 $\beta$ significantly increased

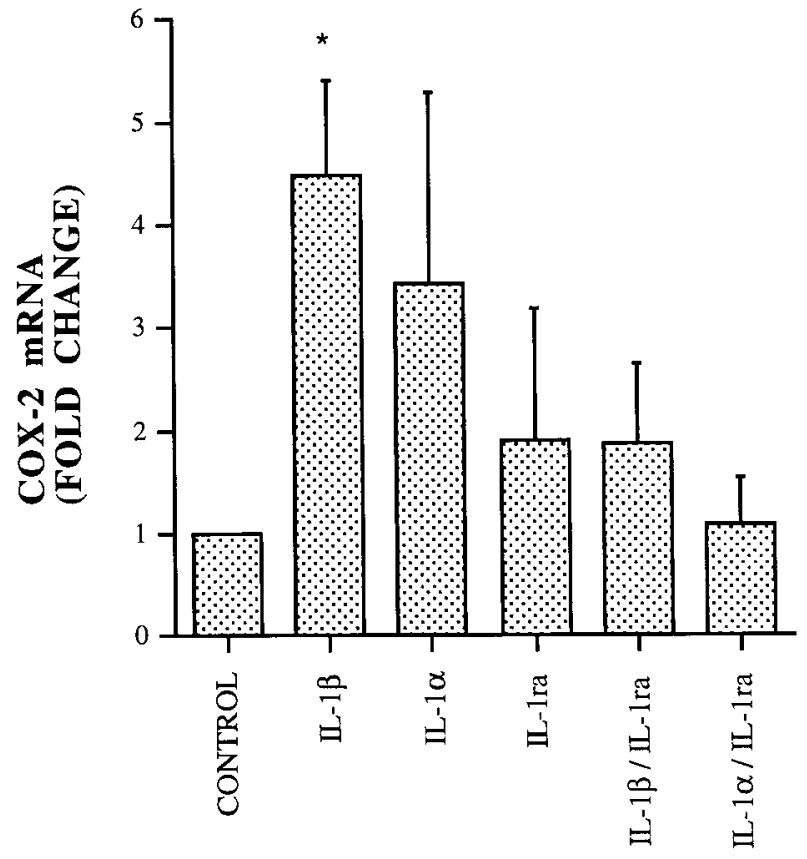

TREATMENT

Figure 3 Changes in the expression of COX-2 transcript after treatment with IL-1 $\beta$, IL- $1 \alpha$ or IL-1ra or combinations of these treatments for $4 \mathrm{~h}$. The COX-2 mRNA levels in each sample were calculated relative to GAPDH and then expressed as fold change compared with the control. The results are mean \pm S.E.M. for three experiments in which each treatment was performed in triplicate. *Statistically significant difference $(P<0 \cdot 05)$.

$\mathrm{PGE}_{2}$ output from fetal membranes over twofold compared with control levels after $4 \mathrm{~h}$ of treatment, whereas IL-1 $\alpha$ was less potent (Fig. 1). IL-1ra alone did not increase prostaglandin release. When IL-1 $\beta$ and IL-1ra were incubated together, $\mathrm{PGE}_{2}$ production was increased more than with IL-1 $\beta$ alone. The combination of IL- $1 \alpha$ and IL-1ra caused the same increase in $\mathrm{PGE}_{2}$ output as IL-1 $\alpha$ alone.

A similar pattern was found when the levels of COX-2 protein were investigated by immunoblotting (Fig. 2). There was a significant increase with IL- $1 \beta$ plus IL-1ra and also with IL-1ra treatment on its own. Treatment with IL- $1 \alpha$ or IL- $1 \alpha$ plus IL- 1 ra did not significantly increase the levels of COX-2 protein. Immunoblots were also performed for the COX-1 isoform. However, only very low levels of COX-1 could be detected which were not affected by any of the treatments (results not shown).

Expression of COX-1 and COX-2 mRNA was investigated using RT-PCR. COX-1 cDNA was detected in very low amounts using high cycle numbers (data not shown). As expected, COX-2 was highly abundant in fetal membranes incubated with IL-1 $\beta$, a significant fourfold increase in mRNA levels over those in controls being observed after $4 \mathrm{~h}$ of treatment (Fig. 3). Once again, IL-1 $\alpha$ 


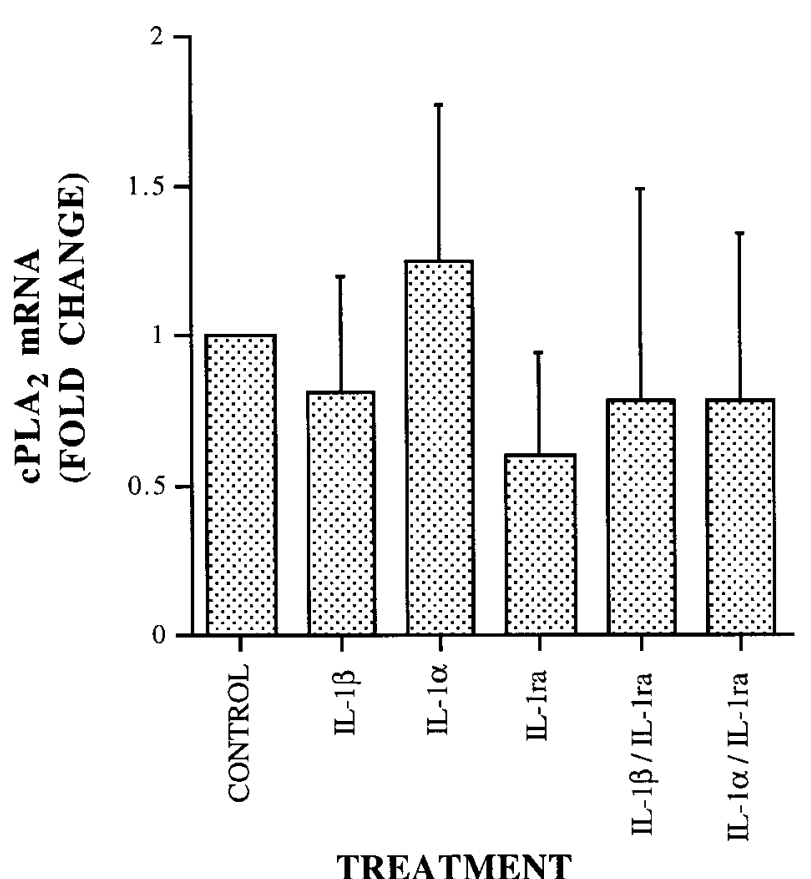

Figure 4 Changes in the expression of $\mathrm{CPLA}_{2}$ mRNA following treatment for $4 \mathrm{~h}$ with IL-1 $\beta$, IL-1 $\alpha$ or IL- 1 ra or combinations of these treatments. The levels of $\mathrm{CPLA}_{2}$ in each sample were expressed relative to GAPDH and then expressed as a fold change compared with the control. The results are mean \pm S.E.M. for three experiments and each treatment was performed in triplicate.

was less potent, with a trend towards an increase in COX-2 mRNA expression that was not significant. IL-1ra did not increase COX-2 mRNA expression and reduced IL-1 $\beta$-upregulated COX-2 mRNA by half.

Expression of cPLA ${ }_{2}$ mRNA after $4 \mathrm{~h}$ of treatment was investigated by RT-PCR (Fig. 4). This was found to be abundant but no significant changes were found with any of the treatment groups relative to control levels. Longer treatments with IL-1 $\beta$ for time periods of up to $72 \mathrm{~h}$ similarly did not result in an increase in $\mathrm{CPLA}_{2}$ mRNA expression (data not shown). Expression of SPLA $_{2}$ mRNA was also investigated; only very low levels could be detected after high PCR cycle numbers (data not shown).

Phosphorylation of $\mathrm{CPLA}_{2}$ reduces its electrophoretic mobility, which offers a convenient way of following agonist-induced changes in the phosphorylated state. Possible changes in the phosphorylated state of $\mathrm{CPLA}_{2}$ after the various treatments were therefore investigated (Fig. 5). IL-1 $\beta$, IL-1 $\alpha$, IL-1ra and IL-1 $\beta$ plus IL-1ra treatment all significantly increased the amount of phosphorylated protein but did not change the ratio of the phosphorylated to unphosphorylated form.

Translocation of $\mathrm{CPLA}_{2}$ from the cytosol to the endoplasmic reticulum (ER) and nuclear membranes after $2 \mathrm{~h}$ of each of the different treatments was also investigated (Fig. 6A-C). IL-1 $\beta$ and IL-1 $\alpha$ produced a significant
(A)

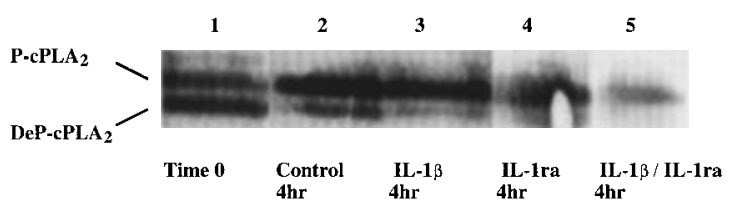

(B)

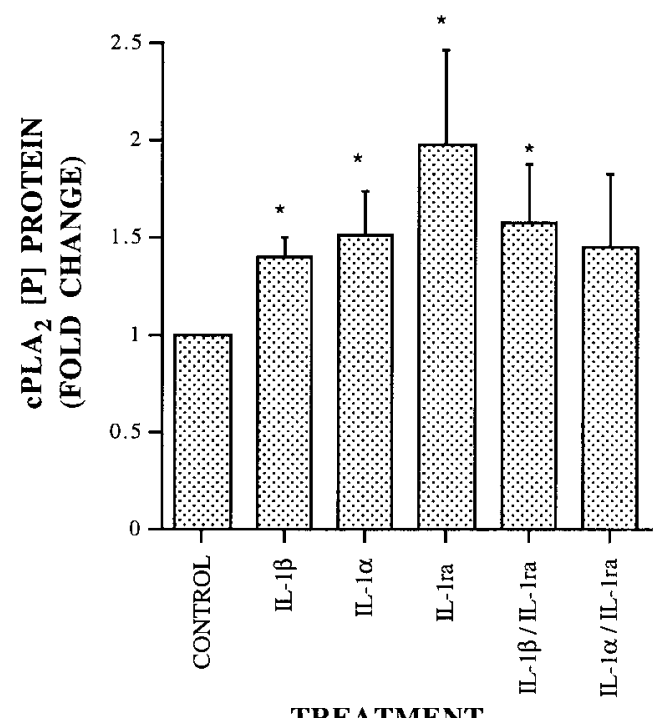

Figure 5 (A) Immunoblot showing the phosphorylation status of ${ }_{C P L A}$ after treatment with IL-1 $\beta$ or IL-1ra. P-CPLA ${ }_{2}$, phosphorylated enzyme; DeP-CPLA ${ }_{2}$, unphosphorylated form of the enzyme. (B) Analysis of three immunoblots by densitometry showing the integrated density (mean \pm S.E.M.). The $\mathrm{CPLA}_{2}$ levels in each sample were corrected for the integrated density of $\beta$-actin and then expressed as fold change compared with the control. * Statistically significant difference $(P<0 \cdot 05)$.

increase in CPLA $_{2}$ translocation from the cytosol to the membrane. Treatment with IL-1ra alone and IL-1 $\beta$ plus IL-1ra resulted in an approximately equal distribution between the cytosol and membrane and an overall significant increase in the total mass of $\mathrm{CPLA}_{2}$ (Fig. 6D).

\section{Discussion}

This study examined the mechanisms by which IL- $1 \alpha$, IL-1 $\beta$ and IL-1ra regulate prostaglandin biosynthesis in intact fetal membranes collected at term. The tissue explants used consisted of adherent amnion, chorion and decidua, which is a better representation of in vivo conditions than isolated cell types. IL-1 $\beta$ was found to be a potent stimulator of $\mathrm{PGE}_{2}$ production from intact fetal membranes, which is consistent with studies performed using amnion and decidual cells (Mitchell et al. 1993a, Albert et al. 1994, Cole et al. 1995, Kennard et al. 1995, 


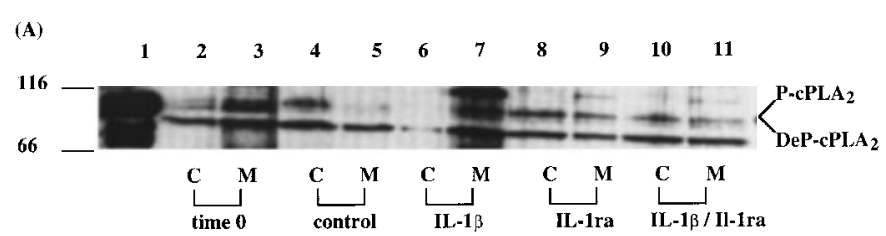

(C)

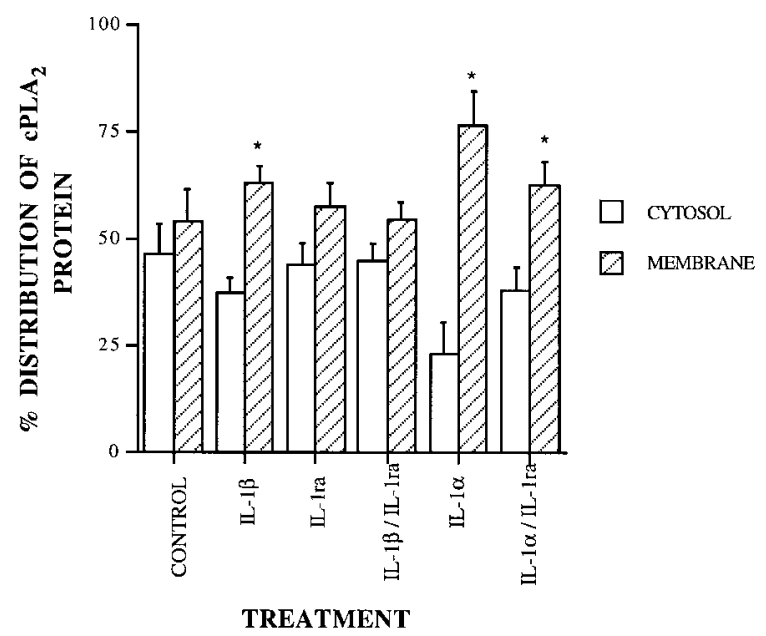

(B)
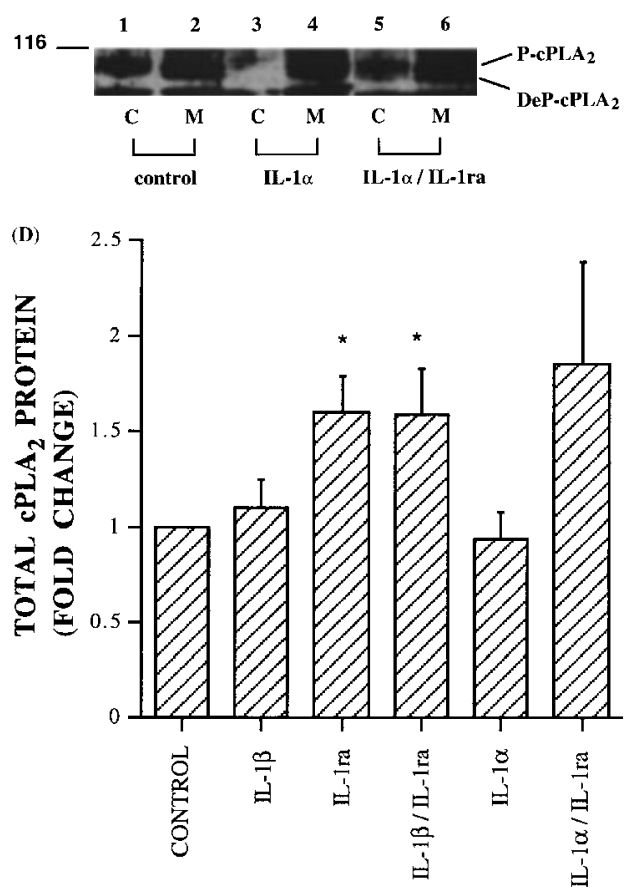

TREATMENT

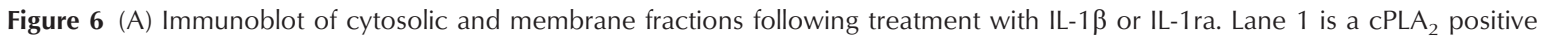
control. (B) Immunoblot of cytosolic and membrane fractions following treatment with IL-1 $\alpha$ or IL-1ra. (C) Analysis of three immunoblots by densitometry showing the percentage distribution of total $\mathrm{CPLA}_{2}$ in either the cytosolic or membrane fractions after $2 \mathrm{~h}$ of each of the treatments. (D) Change in total $\mathrm{CPLA}_{2}$ levels (combining those found in the cytosolic and membrane fractions). Results shown are the integrated density (mean \pm S.E.M.) where ${ }_{C P L A}$ levels were corrected for $\beta$-actin concentration and expressed as fold change compared with the control. *Statistically significant difference $(P<0 \cdot 05)$.

Xue et al. 1995). This increase in $\mathrm{PGE}_{2}$ production was associated with a large increase in COX-2 mRNA expression (Fig. 3). The increase in COX-2 protein was less dramatic than that of COX-2 mRNA (Fig. 2). This is probably due to the instability of COX-2 protein, which has a half-life of approximately $30 \mathrm{~min}$ (DeWitte \& Meade 1993, Evett et al. 1993). COX-2 mRNA is also unstable (DeWitte \& Meade 1993), and IL-1 $\beta$ may cause upregulation of its expression to compensate for this. IL-1 ra reduced IL-1 $\beta$-stimulated COX-2 mRNA expression by half, which almost reached significance $(P=0 \cdot 083)$, suggesting that it antagonises the effects of IL-1 $\beta$ at the mRNA level. Other workers have found that IL-1ra suppressed IL-1 $\alpha$-driven prostaglandin synthesis in human endometrial cells by inhibiting the induction of COX-2 mRNA and protein (Kniss et al. 1997). This group also found that when endometrial cells were incubated with IL-1ra at a dose of $10 \mathrm{ng} / \mathrm{ml}$, prostaglandin production was significantly higher than the control, suggesting that IL-1ra may have partial agonist-like properties.

CPLA $_{2}$ is selective for phospholipids with arachidonic acid in the $s n-2$ position and has been shown to be coupled to the hormonal release of arachidonic acid (Lin et al. 1992a), and the accumulation of CPLA $_{2}$ has been reported after IL-1 treatment (Lin et al. 1992b, Angel et al. 1994, Xue et al. 1995). It is therefore probably involved in receptor-mediated eicosanoid production. Two mechanisms are involved in the activation of $\mathrm{CPLA}_{2}$ : it may be post-translationally modified by phosphorylation, which increases enzyme activity, and this is followed by $\mathrm{Ca}^{2+}$-dependent translocation to the ER and nuclear membranes.

None of the IL-1 family was found to change the expression of $\mathrm{CPLA}_{2}$ transcript in the time period studied. Longer incubations with IL-1 $\beta$ of up to $72 \mathrm{~h}$ were also performed but no increases in $\mathrm{CPLA}_{2}$ mRNA were found. Therefore post-transcriptional changes in $\mathrm{CPLA}_{2}$ may be responsible for the increases in $\mathrm{PGE}_{2}$ production found. In our study of the activation of $\mathrm{CPLA}_{2}$ by phosphorylation and $\mathrm{Ca}^{2+}$-mediated translocation to the nuclear envelope and/or ER, increased levels of the phosphorylated form of ${ } \mathrm{PLA}_{2}$ were found after treatment with IL-1 $\beta$, IL- $1 \alpha$, IL-1ra and IL-1 $\beta$ plus IL-1ra. This was a result of increased $c \mathrm{PLA}_{2}$ protein mass rather than a change in the ratio of phosphorylated to unphosphorylated protein and 
therefore a higher level of active protein compared with the control. This induction by IL- $1 \beta$ of $\mathrm{CPLA}_{2}$ protein levels without a change in the phosphorylation status of the enzyme has also been reported in amnion-derived WISH cells (Honican et al. 1998).

IL-1 $\beta$ increased translocation of $\mathrm{CPLA}_{2}$ to the membrane compared with the control. As $\mathrm{Ca}^{2+}$ appears to be essential for $\mathrm{cPLA}_{2}$ activation, IL-1 may stimulate the production of a $\mathrm{Ca}^{2+}$-mobilising agent (Ikeda et al. 1990). Translocation was inhibited by IL-1ra, with equal distribution in the cytosol and membrane fractions. However, IL-1ra treatment did lead to an increase in $\mathrm{CPLA}_{2}$ mass compared with treatment with IL-1 $\beta$ alone. This may be the mechanism by which IL-1ra enhances the effect of IL-1 $\beta$, i.e. it increases $\mathrm{CPLA}_{2}$ mass which can then mobilise more substrate to be metabolised by COX to give $\mathrm{PGE}_{2}$.

Unfortunately, the assay used for $\mathrm{CPLA}_{2}$, which measured the release of radiolabelled arachidonic acid from arachidonyl-containing phospholipid, was not sensitive enough to give accurate measurements in the tissue explants.

COX-1 and sPLA $\mathrm{A}_{2}$ transcripts were virtually undetectable after treatment with IL-1 $\beta$, IL- $1 \alpha$ or IL- 1 ra and are therefore probably not involved in their regulatory mechanism. A similar finding has been reported for the treatment of human synovial cells with IL-1 (Angel et al. 1994).

In conclusion, IL-1 $\beta$ activates $\mathrm{PGE}_{2}$ output from fetal membranes by upregulating COX-2 gene expression and increasing the translocation of $\mathrm{CPLA}_{2}$ from the cytosol to the cellular membranes. IL- $1 \alpha$ is a less potent activator of $\mathrm{PGE}_{2}$ output by similar mechanisms. A very important finding was that IL-1ra can upregulate $\mathrm{PGE}_{2}$ production from IL- $1 \beta$-stimulated fetal membrane explants, and this appeared to be as a result of increasing CPLA $_{2}$ protein levels. As the transcript levels do not change, it suggests that IL-1ra may stabilise either the mRNA or the protein. It has been postulated that IL-1 ra may bind to the decoy type II IL-1 receptor, thereby dislodging any bound IL-1, which could then in turn bind to the type I receptor (Kniss et al. 1997). However, the results of our study suggest that IL-1ra has different effects on the prostaglandin pathway than those of IL-1 $\beta$ : it acts on $\mathrm{CPLA}_{2}$ protein levels, whereas IL- $1 \beta$ acts primarily by upregulating COX-2. IL-1ra has been found to block IL-1-induced prostaglandin production by amnion and chorion primary cells (Romero et al. 1992b) and so it would be appear that IL-1ra has a unique role in the decidua. The signal transduction pathway by which IL-1ra achieves this effect is beyond the scope of this paper and needs to be addressed in future work.

\section{Acknowledgements}

We would like to thank Action Research (NLB) and WellBeing (SAA) for supporting this work. We would also like to thank the Genetics Institute Inc, MA, USA for supplying us with a sample of pure $\mathrm{CPLA}_{2}$ protein. We also gratefully acknowledge Dr Steve Dilworth for allowing us to use his image scanner and the Bioimage Whole Band Analyser software.

\section{References}

Albert TJ, Su H-C, Zimmerman PD, Iams JD \& Kniss DA 1994 Interleukin- $1 \beta$ regulates the inducible cyclooxygenase in amnionderived wish cells. Prostaglandins 48 401-416.

Angel J, Berenbaum F, Le Denmat C, Nevalainen T, Masliah J \& Fournier C 1994 Interleukin-1-induced prostaglandin $\mathrm{E}_{2}$ biosynthesis in human synovial cells involves the activation of cytosolic phospholipase $\mathrm{A}_{2}$ and cyclooxygenase-2. European Journal of Biochemistry 226 125-131.

Arend WP 1991 Interleukin 1 receptor antagonist: a new member of the interleukin 1 family. Journal of Clinical Investigation $\mathbf{8 8}$ 1445-1451.

Brown NL, Alvi SA, Elder MG, Bennett PR \& Sullivan MHF 1998 A spontaneous induction of fetal membrane prostaglandin production precedes clinical labour. Journal of Endocrinology 157 R1-R6.

Buhl W-J, Eisenlohr LM, Preuss I \& Gehring U 1995 A novel phospholipase $A_{2}$ from human placenta. Biochemical Journal 311 147-153.

Carraher R, Hahn DW, Ritchie DM \& McGuire JL 1983 Involvement of lipoxygenase products in myometrial contractions. Prostaglandins 26 23-32.

Challis JRG \& Olson DM 1988 Parturition. In The Physiology of Reproduction, p 2177. Eds E Knobil \& J Neill. New York: Raven Press.

Chomczynski P \& Sacchi N 1987 Single-step method of RNA isolation by guanidinium thiocyanate-phenol-chloroform extraction. Analytical Biochemistry 162 156-159.

Clark JD, Lin L-L, Kriz RW, Ramesha CS, Sultzman LA, Lin AY, Milona N \& Knopf JL 1991 A novel arachidonic acid-selective cytosolic PLA $\mathrm{P}_{2}$ contains a $\mathrm{Ca}^{2+}$-dependent translocation domain with homology to PKC and GAP. Cell 65 1043-1051.

Cole OF, Sullivan MHF \& Elder MG 1993 The interleukin-1 receptor antagonist is a partial agonist of prostaglandin synthesis by human decidual cells. Prostaglandins 46 493-498.

Cole OF, Seki H, Elder MG \& Sullivan MHF 1995 Interleukin-1 $\beta$ independently stimulates production of prostaglandin $\mathrm{E}_{2}$ and cyclic AMP from human decidual cells. Biochimica et Biophysica Acta 1269 139-144.

Croxtall JD, Choudhury Q, Newman S \& Flower RJ 1996 Lipocortin 1 and the control of cPLA 2 activity in A549 cells. Glucocorticoids block EGF stimulation of CPLA $_{2}$ phosphorylation. Biochemical Pharmacology 52 351-356.

DeWitte DL \& Meade EA 1993 Serum and glucocorticoid regulation of gene transcription and expression of the prostaglandin $\mathrm{H}$ synthase-1 and prostaglandin $\mathrm{H}$ synthase-2 isozymes. Archives of Biochemistry and Biophysics 306 94-102.

Duchesne MJ, Thaler-Dao H \& Crastes de Paulet A 1978 Prostaglandin synthesis in human placenta and fetal membranes. Prostaglandins 15 19-42.

Ellwood DA, Mitchell MD \& Anderson ABM 1980 The in vitro production of prostanoids by the human cervix during pregnancy: preliminary observations. British Journal of Obstetrics and Gynaecology 87 210-214.

Evett GE, Xie W, Chipman JE, Robertson DL \& Simmons DL 1993 Prostaglandin G/H synthase isoenzyme 2 expression in fibroblasts: regulation by dexamethasone, mitogens, and oncogenes. Archives of Biochemistry and Biophysics 306 169-177. 
Hirst JJ, Teixeira FJ, Zakar T \& Olson DM 1995 Prostaglandin-H synthase-1 and -2 messenger ribonucleic acid levels in human amnion with spontaneous labor onset. Journal of Clinical Endocrinology and Metabolism 80 517-523.

Hla T \& Neilson K 1992 Human cyclo-oxygenase-2 cDNA. Proceedings of the National Academy of Sciences of the USA 89 7384-7388.

Hla T, Farrell M, Kumar A \& Bailey JM 1986 Isolation of the cDNA for human prostaglandin H synthase. Prostaglandins 32 829-845.

Honican D, Brockman DE \& Myatt L 1998 Transcriptional and post-translational regulation of cytosolic phospholipase $\mathrm{A}_{2}$ by IL-1 and EGF in WISH cells. Journal of the Society for Gynecologic Investigation 5 59A (Abstract no. 81).

Ikeda U, Ikeda M, Oohara T, Kano S \& Yaginuma T 1990 Mitogenic action of interleukin-1 alpha on vascular smooth muscle cells mediated by PDGF. Atherosclerosis 84 183-188.

Ishihara O, Numari H, Saitoh M, Arai Y, Takanashi H, Kitagawa H \& Kinoshita K 1996 Prostaglandin E2 production by endogenous secretion of interleukin-1 in decidual cells obtained before and after the labor. Prostaglandins 52 199-208.

Kennard EA, Zimmerman PD, Friedman CI \& Kniss DA 1995 Interleukin-1 beta induces cyclooxygenase- 2 in cultured human decidual cells. American Journal of Reproductive Immunology 34 65-71.

Kniss DA, Zimmerman PD, Fertel RH \& Iams JD 1992 Proinflammatory cytokines interact synergistically with epidermal growth factor to stimulate $\mathrm{PGE}_{2}$ production in amnion-derived cells. Prostaglandins $44237-244$

Kniss DA, Zimmerman PD, Garver CL \& Fertel RH 1997 Interleukin-1 receptor antagonist blocks interleukin-1-induced expression of cyclooxygenase in endometrium. American Journal of Obstetrics and Gynecology 177 559-567.

Lin L-L, Lin AY \& Knopf JL 1992a Cytosolic phospholipase $A_{2}$ is coupled to hormonally regulated release of arachidonic acid. Proceedings of the National Academy of Sciences of the USA 89 6147-6151.

Lin L-L, Lin AY \& DeWitt DL $1992 b$ Interleukin-1 $\alpha$ induces the accumulation of cytosolic phospholipase $\mathrm{A}_{2}$ and the release of prostaglandin $\mathrm{E}_{2}$ in human fibroblasts. Journal of Biological Chemistry 267 23451-23454.

McMahan CJ, Slack JL, Mosley B, Cosman D, Lupton SD, Brunton LL, Grubin CE, Wignall JM, Jenkins NA, Brannan CI, Copeland NG, Huebner K, Croce CM, Cannizzaro LA, Benjamin D, Dower SK, Spriggs MK \& Sims JE 1991 A novel IL-1 receptor cloned from $\mathrm{B}$ cells by mammalian expression is expressed in many cell types. EMBO Journal 10 2821-2832.

Mitchell MD, Dudley DJ, Edwin SS \& Schiller SL 1991 Interleukin-6 stimulates prostaglandin production by human amnion and decidual cells. European Journal of Pharmacology 192 189-191.

Mitchell MD, Edwin SS, Lundin-Schiller S, Silver RM, Smotkin D \& Trautman MS 1993a Mechanism of interleukin-1 beta stimulation of human amnion prostaglandin biosynthesis: mediation via a novel inducible cyclooxygenase. Placenta 14 615-625.

Mitchell MD, Edwin S, Silver RM \& Romero RJ 19936 Potential agonist action of the interleukin-1 receptor antagonist: implications for treatment of women. Journal of Clinical Endocrinology and Metabolism 76 1386-1388.

Norwitz ER, Lopez Bernal A \& Starkey PM 1992 Tumor necrosis factor- $\alpha$ selectively stimulates prostaglandin $\mathrm{F}_{2 \alpha}$ production by macrophages in human term decidua. American Journal of Obstetrics and Gynecology 167 815-820.

Olson DM \& Zakar T 1993 Intrauterine tissue prostaglandin synthesis: regulatory mechanisms. Seminars in Reproductive Endocrinology 11 234.

Rittenhouse J \& Marcus F 1984 Peptide mapping by polyacrylamide gel electrophoresis after cleavage at aspartyl-prolyl peptide bonds in sodium dodecyl sulfate-containing buffers. Analytical Biochemistry $138442-448$
Romero R \& Tartakovsky B 1992 The natural interleukin-1 receptor antagonist prevents interleukin-1 induced preterm delivery in mice. American Journal of Obstetrics and Gynecology 167 1041-1045.

Romero R, Brody DT, Oyarzun E, Mazor M \& Wu YK 1989 Infection and labour. III. Interleukin-1: a signal for the onset of parturition. American Journal of Obstetrics and Gynecology 160 $1117-1123$

Romero R, Parvizi ST, Oyarzun E, Mazor M, Wu YK, Avila C, Athanassiadis A \& Mitchell MD 1990 Amniotic fluid interleukin-1 in spontaneous labor at term. Journal of Reproductive Medicine 35 235-238.

Romero RJ, Sepulveda W, Mazor M, Brandt F, Cotton DB, Dinarello CA \& Mitchell MD 1992 The natural interleukin-1 receptor antagonist in human amniotic fluid in term and preterm parturition. American Journal of Obstetrics and Gynecology 167 863-872.

Schultz BE, Schwarz BE, MacDonald PC \& Johnston JM 1975 Initiation of human parturition. IV. Demonstration of phospholipase $\mathrm{A}_{2}$ in fetal chorioamnion and uterine decidua. American Journal of Obstetrics and Gynecology 123 650-653.

Seilhamer J, Pruzanski W, Vadas P, Plant S, Miller J, Kloss J \& Johnson L 1989 Cloning and recombinant expression of phospholipase $A_{2}$ present in rheumatoid arthritic synovial fluid. Journal of Biological Chemistry 264 5335-5338.

Sims JE, Acres RB, Grubin CE, McMahan CJ, Wignall JM, March CJ \& Dower SK 1989 Cloning of the interleukin 1 receptor from human T cells. Proceedings of the National Academy of Sciences of the USA 86 8946-8950.

Sims JE, Gayle MA, Slack JL, Alderson MR, Bird TA, Giri JG, Colotta F, Re F, Mantovani AM, Shanebeck K, Grabstein KH \& Dower SK (1993) Interleukin 1 signaling occurs exclusively via the type 1 receptor. Proceedings of the National Academy of Sciences of the USA $906155-6159$.

Skannal DG, Brockman DE, Eis ALW, Xue S, Siddiqi TA \& Myatt L 1997 Changes in activity of cytosolic phospholipase $A_{2}$ in human amnion at parturition. American Journal of Obstetrics and Gynecology 177 179-184

Slater DM, Berger LC, Newton R, Moore GE \& Bennett PR 1995 Expression of cyclooxygenase types 1 and 2 in human fetal membranes at term. American Journal of Obstetrics and Gynecology 172 $77-82$.

Smieja Z, Zakar T, Walton J \& Olson DM 1993 Prostaglandin endoperoxide synthase kinetics in human amnion before and after labor at term and following preterm labor. Placenta 14 163-175.

Takahashi Y, Ueda N, Yoshimoto T, Yamamoto S, Yokoyama C, Miyata A, Tanabe T, Fuse I, Hattori A \& Shibata A 1992 Immunoaffinity purification and cDNA cloning of human platelet prostaglandin endoperoxide synthase (cyclo-oxygenase). Biochemical and Biophysical Research Communications 182 433-438.

Teixeira FJ, Zakar T, Hirst JJ, Guo F, Sadowsky DW, Machin G, Demianczuk N, Resch B \& Olson DM 1994 Prostaglandin endoperoxide-H synthase (PGHS) activity and immunoreactive PGHS-1 and PGHS-2 levels in human throughout gestation, at term, and during labor. Journal of Clinical Endocrinology and Metabolism 78 1396-1402.

Tso JY, Sun XH, Kao TH, Reece KS \& Wu R 1985 Isolation and characterisation of rat and human glyceraldehyde-3-phosphate dehydrogenase cDNAs: genomic complexity and molecular evolution of the gene. Nucleic Acids Research 13 2485-2502.

Xue S, Brockman DE, Slater DM \& Myatt L 1995 Interleukin-1 $\beta$ induces the synthesis and activity of cytosolic phospholipase $A_{2}$ and the release of prostaglandin $\mathrm{E}_{2}$ in human amnion-derived WISH cells. Prostaglandins 49 351-369.

Received 18 May 1998

Accepted 19 August 1998 